\title{
Pollen development and orbicule and pollen grain morphology in species of Cephalanthus (Rubiaceae-Naucleeae) from the Americas
}

\author{
María Florencia Romero ${ }^{\mathrm{A}, \mathrm{D}}$, Roberto Salas ${ }^{\mathrm{A}, \mathrm{B}}$ and Ana Maria Gonzalez ${ }^{\mathrm{A}, \mathrm{C}}$ \\ A Instituto de Botánica del Nordeste (IBONE, UNNE-CONICET), Sargento Cabral 2131, C.P. 3400, \\ Corrientes, C.C. 209, Argentina. \\ ${ }^{B}$ Facultad de Ciencias Exactas y Naturales y Agrimensura (FaCENA-UNNE), Avenida Libertad 5470, \\ C.P. 3400, Corrientes, Argentina. \\ C Facultad de Ciencias Agrarias (FCA-UNNE), Sargento Cabral 2131, C. P. 3400, Corrientes, Argentina. \\ DCorresponding author. Email: mariafloromero@gmail.com
}

\begin{abstract}
This paper is the first embryological report on the genus Cephalanthus L. and contributes to future studies in other genera of the tribe Naucleeae. The development of the anther wall in Cephalanthus glabratus (Spreng.) K. Schum. corresponds to the dicot type and microsporogenesis is simultaneous. The young wall of the anther has four layers; epidermis, endothecium, one middle layer and the secretory tapetum. The tissue of the septum has idioblasts with crystalline sand. In the wall of the mature anther, only the endothecium and remnants of epidermal cells were preserved. The occurrence and morphology of orbicules were observed in the mature anthers of all three species of Cephalanthus with scanning electron microscopy. The orbicules have taxonomic value at species level, since these structures allow us to distinguish between the species analysed. The presence of a protruding oncus was observed for the first time in Cephalanthus in non-acetolysed pollen grains. According to our observations, this structure is not affected by the state of anther dehiscence in C. glabratus because the oncus is visible and prominent in the mature pollen grains in both indehiscent and dehiscent anthers.
\end{abstract}

Additional keywords: anther development, Cephalanthus glabratus, microsporogenesis, oncus, orbicules.

Received 24 November 2016, accepted 27 March 2017, published online 30 May 2017

\section{Introduction}

The Rubiaceae is a cosmopolitan family with species that inhabit tropical and subtropical regions. It has 650 genera and 13000 species included in three subfamilies and 44 tribes (Bremer and Eriksson 2009). The genus Cephalanthus L. belongs to the subfamily Cinchonoideae (Bremer et al. 1999), in the tribe Naucleeae, along with another 26 genera of which only Cephalanthus has any American species. This tribe is characterised by globose inflorescences, nectaries included in the hypanthium, and a secondary mechanism of displaying immature pollen on the stigma lobes (Manns and Bremer 2010).

According to Ridsdale (1976), the American species of Cephalanthus have a markedly disjoint distribution: Cephalanthus occidentalis L. and Cephalanthus salicifolius Humb. and Bonpl. occur in southern North America and Mesoamerica, whereas Cephalanthus glabratus (Spreng.) K. Schum. inhabits the southern cone of South America. The latter species, commonly known as 'red sarandi', is found naturally in southern Brazil, northern Uruguay, eastern Paraguay and north-eastern Argentina (Cabrera and Zardini 1978).
Cephalanthus glabratus is a shrub or small tree $2-5 \mathrm{~m}$ tall, deciduous or with semi-persistent foliage, the leaves are in trimerous whorls and it has stalked globose inflorescences. The flowers are white, sessile, and gently scented with cinnamon (Bacigalupo 1974). C. glabratus is a rheophile plant, naturally adapted to withstanding temporary flooding and strong water currents (Siegloch et al. 2011), which, together with its small size and easy vegetative propagation, give it great potential for bioengineering. This shrub is credited with important medicinal properties (Martínez Crovetto 1981) and it is also a honeybee forage species used by local communities in wetlands or on islands in the Paraná River, as it has profuse flowering for 6-7 months of the year (Arbo et al. 2002; Kandus et al. 2010). In some areas of the Iberá system it is an important beekeeping resource because it is one of the few woody elements found in the area (Salas, R.M., pers. comm.).

The first embryological studies in the family were conducted by Schleiden (1837), Devi (1980) and Inamuddin and Farooq (1984). More recent studies were conducted by Galati (1991), Vinckier and Smets (2005) and Cabaña Fader 
(2013). However, no embryological data for the tribe Naucleeae are known, neither are there any records for the Cephalanthus genus.

The taxonomic value of orbicules has been studied in several families: Loganiaceae, Gentianaceae, Apocynaceae, Oxalidaceae and Rubiaceae. Orbicules appear to be a common feature of the anthers of Rubiaceae-Cinchonideae and may be useful systematically at generic and tribal levels (Huysmans et al. 1997). Verstraete et al. (2011) confirm for the Rubiaceae that the absence of orbicules occurs in the more derived taxa. They observed a trend from spherical to irregular orbicules, while ornamented orbicules only occur in derived lineages. Although orbicules are common among angiosperms, their function is unknown and only speculations have been made. Huysmans et al. (1998), working in Cinchonoideae (Rubiaceae) cited some of them: (i) the orbicules represent a transport mechanism of sporopollenin between the tapetum and developing microspores, (ii) temporary packaging for transporting material through the locule, (iii) the orbicules would be products of the tapetal cells, (iv) they are associated with pollen dispersal, (v) they have a role in the degradation of the tapetal cells, and (vi) they act as prevention against osmosis and the collapse of microspore development. According to Davis (1966), orbicules could be the cause of allergic reactions in susceptible individuals (Vinckier and Smets 2002). Galati et al. (2010) studied the relationship between orbicule morphology and the mode of pollination.

Tricolporate pollen grain is the dominant type in Rubiaceae and all representatives of the family present openings located on the equator. The exine is generally tectate or semitectate, varying from almost closed to reticulate (Robbrecht 1988). The oncus (pl. onci) is an intinous structure occurring beneath the apertures of many types of pollen grains (Hyde 1955). At the apertures, onci protrude through the apertures forming papillae, a common feature in Rubiaceae (Vinckier and Smets 2005). All Naucleeae taxa investigated were tri-colporate and the largest pollen grains were observed in Adina Salisb. and Cephalanthus (Verellen et al. 2007).

In the absence of embryological data, the objectives of this study were to: (a) perform an ontogenetical study of anthers, (b) describe microsporogenesis and microgametogenesis to document and better understand the reproductive aspects of Cephalanthus glabratus, a widely distributed species in Argentina, and (c) examine its pollen grain morphology and the presence or absence of orbicules in three species of Cephalanthus from the Americas.

\section{Materials and methods}

The materials selected for this study were deposited in the Herbarium C. L. Cristóbal (CTES), Instituto de Botánica del Nordeste, Corrientes, Argentina:

Cephalanthus glabratus (Spreng.) K. Schum.: ARGENTINA. Prov. Corrientes: Dpto. Ensenada Grande, Las Lomas, 29 Jul 2015, Romero M.F. and R.M. Salas 60. Dpto. Capital, Riachuelo, 09 Set 2015, Romero M. F. and R. Salas 61.

Cephanthus occidentalis L.: USA. Aransas Country: Aransas Pass, on N. Mc Campbell Road, between Rabbit Road and Jacoby Lane, 3 Jun 1998, Fryxell 5137. Est. Nueva Jersey: Burlington. 23 Jul 1981, Condado de Maricopa: Bosque
Nacional del Tonto, $33^{\circ} 47.93^{\prime} \mathrm{N}, 11^{\circ} 29.49^{\prime} \mathrm{W}, 25$ Jun 1999 , Landrum 9539.

Cephalanthus salicifolius Humb. and Bonpl.: MÉXICO. Est. Nayarit: Mpio. San Blas, 3,8 Km al SE de Tecuitata sobre camino a tierra El Cora, carr. Jalcocotan-Miramar, $21^{\circ} 26^{\prime} 16^{\prime \prime} \mathrm{N}$, $105^{\circ} 08^{\prime} 13^{\prime \prime} \mathrm{W}, 10$ Jun 1994, Flores-Franco 3534.

\section{Light microscopy (LM)}

Flowers at different stages of development were fixed in FAA (formaldehyde, 70\% alcohol, acetic acid, 5:90:5). Measurements of inflorescence diameter and the length of flower buds using an electronic digital caliper (Schwyz) were made to record the button size with respect to the stage of anther development.

The material was dehydrated through histological dehydrating followed by a tertiary butanol series (Gonzalez and Cristóbal 1997) and embedded in paraffin according to the technique of Johansen (1940). Transverse serial sections were cut $12 \mu \mathrm{m}$ thick with a rotary microtome, and stained with Safranin-Astra blue (Luque et al. 1996). The sections were mounted in synthetic Canada balsam. To analyse orbicules, anthers were fixed in $2.5 \%$ glutaraldehyde ( $0.1 \mathrm{~m}$ phosphate buffer, $\mathrm{pH} 7.2)$, dehydrated in an increasing ethanol series, pre-infiltrated and infiltrated in historesin (Leica) according to the manufacturer's recommendations. The material was sectioned to $8 \mu \mathrm{m}$ thick on a rotary microtome. Sections were stained with toluidine blue at pH 4.7 (O'Brien et al. 1964). To determine tannins, transverse microtome sections of paraffin-embedded anthers were treated with $10 \%$ aqueous ferric chloride plus a little sodium carbonate (Johansen 1940).

The observations and photographs were made using a Leica DM LB2 microscope equipped with a digital camera.

\section{Viability of the pollen grains}

Flower buds of $C$. glabratus at the anthesis stage were collected. Anthers were opened longitudinally and free pollen grains were extracted in a drop of Muntzing reagent (acetic carmine and glycerin in a ratio of 1:1) (Muntzing 1941; Marks 1954). The anther remains were removed, coverslips were placed and, after $24 \mathrm{~h}$, the preparation was observed and photographs were taken. ImageJ software was used for counting the viable and non-viable pollen grains (US National Institutes of Health, Bethesda, MA, USA).

\section{Scanning electron microscopy (SEM)}

Buttons and flowers fixed in FAA were dehydrated in an ascending series of acetone, dried to critical point with $\mathrm{CO}_{2}$ and sputter coated with Gold-Palladium. Observations were performed at $20 \mathrm{kV}$ with a SEM Jeol LV5800 at the Electron Microscopy service of the Universidad Nacional del Nordeste.

For the analysis of the pollen grains, samples of the three American species were taken from herbarium specimens of C. occidentalis and C. salicifolius. Rehydration was performed with $5 \%$ neutral detergent in distilled water for $24 \mathrm{~h}$. Samples of the pollen grains were acetolysed according to the technique by Erdtman (1960). The terminology used in pollen descriptions follows that of Punt et al. (2007). Pollen size was classified following work by Dessein et al. (2005): very small, $<20 \mu \mathrm{m}$; 
small, 20-30 $\mu \mathrm{m}$; medium, 30-40 $\mu \mathrm{m}$. For the shape of pollen grains, the ratio of the polar axis $(\mathrm{P})$ and the equatorial diameter $(\mathrm{E})$ were taken into account according to definitions by Nilsson and Praglowski (1992) for the tribe Naucleeae (P/E): suboblate, $0.75-0.88 \mu \mathrm{m}$; spheroidal, 0.88-1.14 $\mu \mathrm{m}$; subprolate, $1.14-1.33 \mu \mathrm{m}$; prolate, $1.33-2.00 \mu \mathrm{m}$.

In order to determine the presence of orbicules after critical point drying, a longitudinal section of each theca was cut using a razor blade, the pollen grain dissecting needle was gently removed, and the theca was metallised.

\section{Results}

\section{Floral structure and morphology}

Cephalanthus glabratus presented perfect flowers, actinomorphic, tetramerous or pentamerous, heterochlamydeous with bracteoles and arranged in glomerulate inflorescences (Fig. $1 a-d$ ). The calyx was pale green with 4-5 (6-7) lobes, fused and lobed (Fig. 1a), their edges were puberulous and they had a dense pubescence on the inner side (Fig. 1f, g). The corolla was white with 4-5 (6-7) lobes joined together forming a tube, glabrous on the outside and pubescent inside the lobes with a fringe of hairs (Fig. 1a, b, d,e). Black colleters were found in fresh flowers on the interlobular sinuses of calyx and corolla (Fig. $1 b, c, f, g$ ). The androecium was formed by 4-5 stamens, the filaments were fixed to the corolla throat; the anthers were sessile and sagittated (Fig. 1e). The apex of the thecae presented a small protuberance that was formed from apiculate connective tissue (Fig. 1e). The gynoecium had a 2-carpellate and 2-locular ovary; each locule was 1-ovulate. The style was filiform with a capitated and exserted stigma (Fig. 1a,b).

\section{Ontogeny of the anther wall}

Anther primordia began to develop as small bumps, hemispherical to sub-triangular in transection (Fig. 2a). Each staminal primordium consisted of meristematic cells arranged in layers named L1, L2 and L3 that develop into different tissues of the anther (Fig. 2b). They had typical meristem cell characteristics: isodiametrical, thin-walled, dense cytoplasm and a voluminous nucleus. Predominantly anticlinal divisions occurred in the outer layer or L1 that contributed to increasing the size of the anther, giving rise to the epidermis and the cells constituting the stomium.

The subepidermal layer (L2) increased the number of divisions at various levels, predominantly in two regions of the anther, oriented towards the centre of the primordium, so that it took a triangular shape (Fig. $2 b-d$ ). In these regions, the mitotic divisions gave rise to the four anther lobes and pollen sacs were eventually formed. In a tetralobulate anther, the arquesporial cells derived from L2 (Fig. 2e) suffered periclinal divisions originating from a primary parietal layer and they formed the sporogenous cells (Fig. 2f, g). Further periclinal mitotic divisions in the primary parietal layer generated two secondary parietal layers: external and internal (Fig. $2 h$ ). The external secondary parietal layer was divided periclinally giving rise to the endothecium and a middle layer, while the inner side of the parietal layer develops into the tapetum (Fig. 2i).

The number of cells in the central region of the anther primordium increased in the innermost layer (L3), and this led to the differentiation of the procambium, forming a central vascular bundle (Fig. 2e). The L3 layer also becomes differentiated into connective tissue and septum that were between the pollen sacs of each theca (Fig. $2 b, h$ ).

Upon completion of the differentiation, the young anther wall was formed by four layers: epidermis, endothecium, middle layer and tapetum.

Epidermis: formed by a layer of rectangular cells covered with a smooth cuticle. It was continuous in the young stages of the anther (Fig. $3 a-c$ ), becoming discontinuous in certain regions when the anther is mature (Fig. $3 d, g$ ). There were no stomata.

Endothecium: formed by quadrangular to radially elongated cells. In the indehiscent anther it formed a continuous layer of cells similar in size to the epidermis (Fig. $3 a-c$ ). As the anther developed, lignified thickenings were formed in the tangential and radial walls of the endothecium cells, which were thicker on the tangential internal face where they anastomose and taper towards the outer tangential face. The endothecium thickenings were formed during the process of microgametogenesis, and formed a mechanical layer that contributed to anther dehiscence (Fig. 3d, g). In the inner zone of the pollen sacs, bordering the connective tissue, several layers of parenchyma developed thickenings and differentiated into the endothecium, which becomes five layers thick (Fig. 3i).

Middle layer: formed by one layer of flattened rectangular cells. This layer had a common origin with the endothecium, forming from periclinal divisions, which was the reason why the wall of the anther was of the dicotyledonous type. (Fig. 3a). The middle layer was ephemeral, as the cells started to collapse quickly when crushed during the expansion of the microspore mother cells (mmc) and tapetal cells (Fig. 3b). In the state of free microspores, this layer was fully collapsed (Fig. 3c).

Tapetum: was the secretory type and it consisted of large rectangular to quadrangular cells. They were uninucleate with dense cytoplasm (Fig. 3a) and a high content of tannic substances (Fig. 3e). This layer began to degenerate gradually at the microspore stage (Fig. 3c). Orbicules could be seen on the inner tangential face of the tapetal cells (Fig. 3f). In the pollen grain stage, the tapetal cells were no longer displayed as the tapetal membrane was associated with the orbicules (Fig. $3 g, h$ ).

Connective tissue: located in the central region of the anther. It differed in the early stages of development, being simultaneously visible with the formation of sporogenous cells and $\mathrm{mmc}$ (Figs $2 h, i, 4 a$ ). It consisted of parenchymal tissue surrounding a collateral vascular bundle and it extended between the pollen sacs forming the septa, consisting of three rows of cells that exhibited crystalline sand formed in the early stages (Fig. $4 b-d$ ). The septum cells became compressed by the expanding pollen sacs during development of the anther (Fig. 4e).

Anther dehiscence occurred before floral anthesis. The anther wall comprised the remains of the epidermal cells on the dorsal face and the endothecium, because the middle layer and the tapetum had degenerated. The septum cells separating the two pollen sacs of each theca collapsed, allowing them to merge resulting in a bilocular anther (Fig. $4 g$ ).

Stomium region is formed by epidermal cells differentiated in the early stages of anther development which were small, 

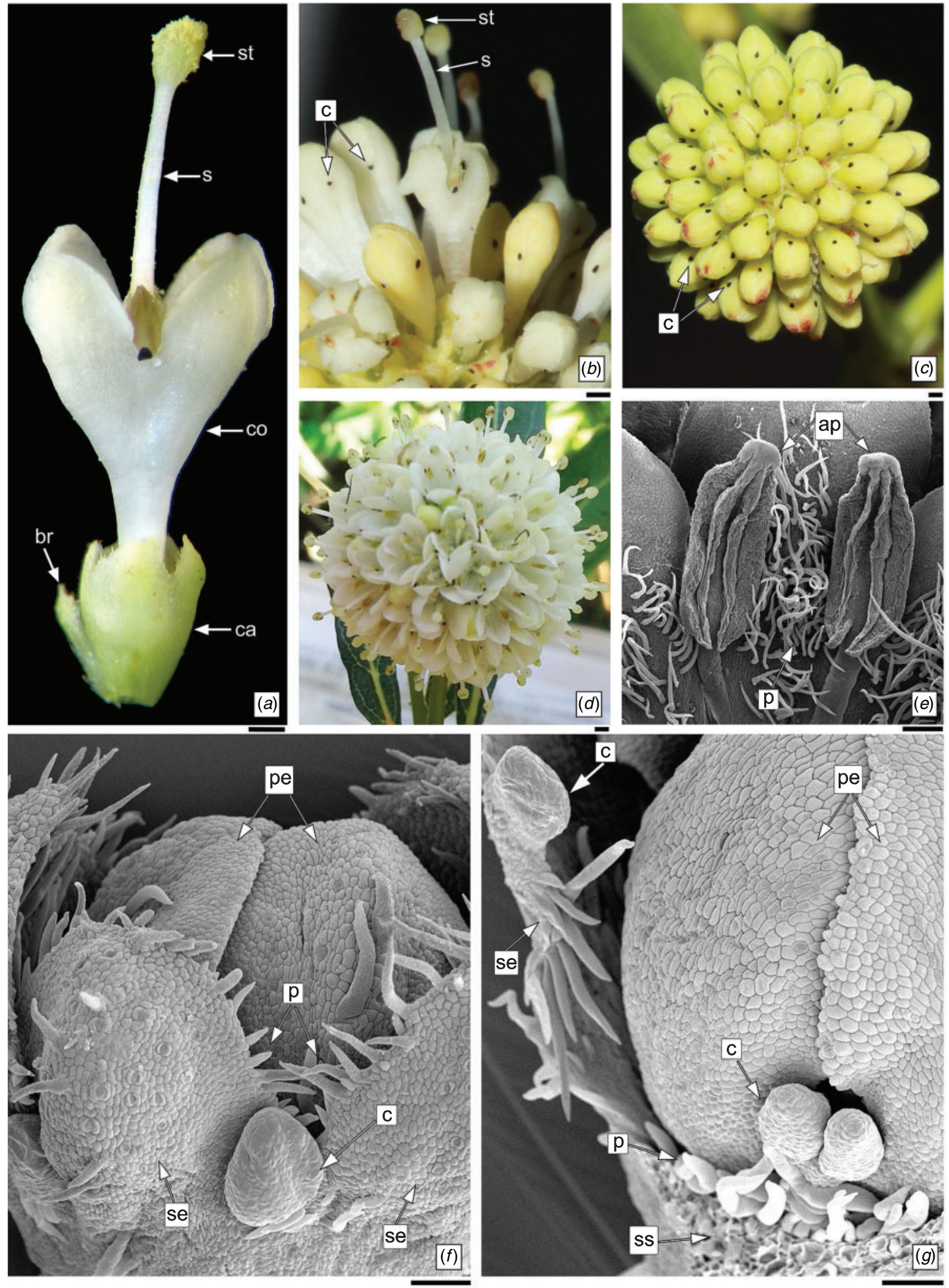

Fig. 1. Floral morphology of Cephalanthus glabratus. $(a, b)$ Flowers; $(c)$ inflorescence in pre-anthesis phase; $(d)$ inflorescence with anthetical flowers; $(e-g)$ scanning electron microscopy; $(e)$ inner view of corolla tube showing pubescence and pair of dehiscent stamens with apical protuberance; $(f)$ colleter between calyx lobes and pubescence on margins of sepals; $(g)$ sepals with colleter and marginal pubescence, one sepal was removed to show the colleters located between the lobes of the corolla. Abbreviations: ap, apical protuberance of anther; br, bracteole; c, colleter; ca, calyx; co, corolla; $p$, pubescence; pe, petals; s, style; se, sepals; ss, scar of removed sepal; st, stigma. Scale bars $=0.5 \mathrm{~mm}(a-d), 200 \mu \mathrm{m}(e)$ and $100 \mu \mathrm{m}(f, g)$. 



Fig. 2. Ontogeny of the anther wall in transverse sections with light microscopy in flower buds the Cephalanthus glabratus: (a) detail of flower bud; $(b)$ anther primordium with layers L1, L2 and L3; $(c)$ anther primordium in triangular shape; $(d)$ detail of periclinal division in L2; $(e)$ tetralobulate anther with arquesporial cells, derived from L2, and procambium derived from L3; $(f)$ anther with primary parietal layer and sporogenous cells; $(g)$ detail of periclinal division in the primary parietal layer (white arrow); $(h)$ anther wall with external and internal secondary parietal layers; (i) detail of four-layered anther young wall. Abbreviations: ar, arquesporial cells; ca, calyx; cn, connective; co, corolla; e, epidermis; en, endothecium; L1, L2, L3, meristematic layers; ml, middle layer; pc, procambium; ppl, primary parietal layer; ple, secondary external parietal layer; pli, secondary internal parietal layer; sc, sporogenous cells; sp, septum; str, stomium region; t, tapetum; v, vascular bundle. Scale bars $=20 \mu \mathrm{m}(a-c, e-i)$ and $5 \mu \mathrm{m}(d)$. 

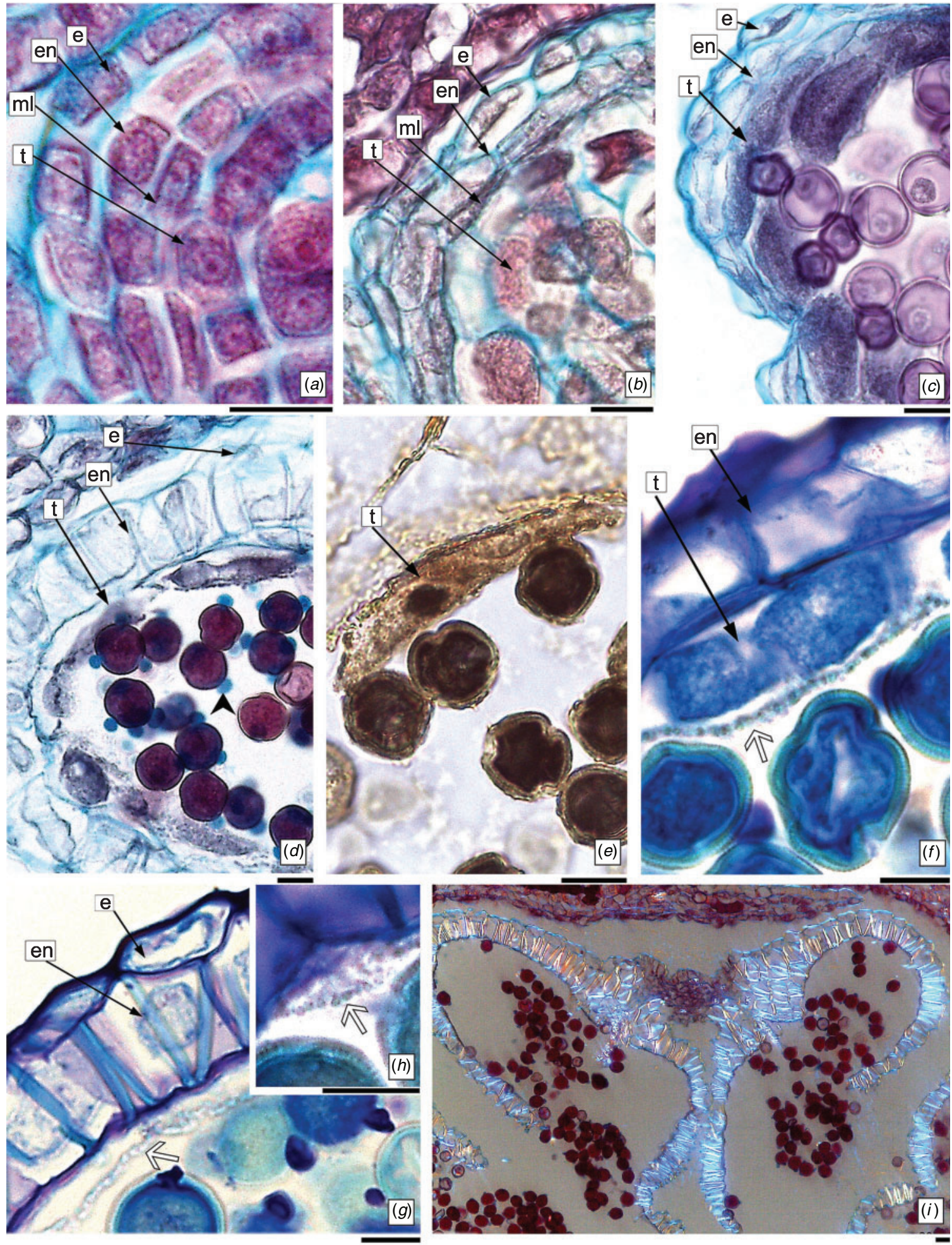

Fig. 3. Anther wall at different stages in transverse sections with light microscopy. $(a, b)$ Young anther with four layers that comprise it; $(a)$ anther in stage of sporogenous cells; $(b)$ anther with microspore mother cells $(\mathrm{mmc})$, the middle layer begins to collapse; $(c)$ anther in free microspores stage; the middle layer has collapsed. $(d-i)$ Mature anther with pollen grains; $(d)$ anther with epidermis, endothecium with fibrous thickening and collapsed tapetum; $(e)$ anther stained with ferric chloride: condensed tannins are seen in the tapetal cell; $(f)$ detail of orbicules on the inner tangential face of the tapetal cells (white arrow); $(g)$ orbicules in tapetal membrane (white arrow); $(h)$ detail of the orbicules (white arrow) once the tapetum completely collapsed; $(i)$ transverse section of dehiscent anther with polarised filter showing fibrous thickening of endothecium. Abbreviations: e, epidermis; en, endothecium; ml, middle layer; $\mathrm{t}$, tapetum. Scale bars $=10 \mu \mathrm{m}(a-h)$ and $20 \mu \mathrm{m}(i)$. 

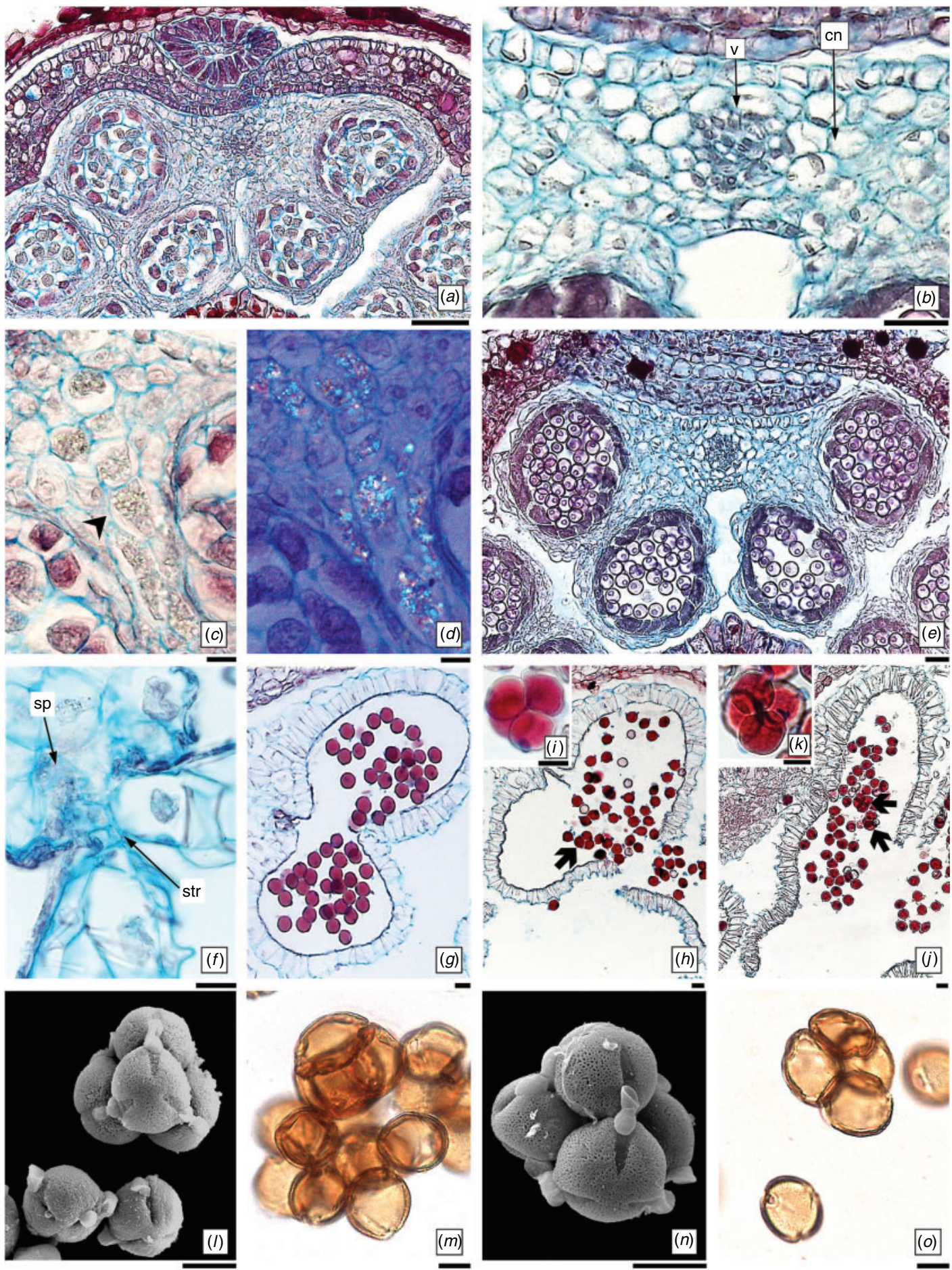

Fig. 4. Characteristics of connective tissue and anther dehiscence in transverse sections with light microscopy $(a-h, j)$ and tetrads of pollen grains with light microscopy $(i, k, m, o)$ and scanning electron microscopy $(l, n)$ of Cephalanthus glabratus. (a) Young anther in microspore mother cells (mmc) stage; $(b)$ detail of connective region with collateral vascular bundle; $(c, d)$ detail of crystalline sand in anther stage of mmc $(d)$ light microscopy with polarised filters; $(e)$ free microspore stage of anther with septal tissue begin to compress; $(f)$ detail of stomium region and septum collapsed cells; $(g)$ fusion of both locules of one theca; $(h, j)$ anthers at different developmental stages of the dehiscence process; $(h)$ anther with pollen grains released into monads and tetrahedral tetrad; (i) detail of pollen grains in tetrahedral tetrad; $(j)$ anther with pollen grains released into monads and decussated tetrad; $(k)$ detail of pollen grains in decussate tetrad; $(l, n)$ pollen grains in tetrad without acetolysis with oncus; $(m, o)$ acetolysed pollen grains in monads and tetrad; $(l, m)$ pollen grains in monads and tetrahedral tetrad; $(n, o)$ pollen grains in decussated tetrad. Note that in the two types of tetrads the pollen grains are united in the region of the colporate. Abbreviations: cn, connective; sp, septum; str, stomium region; v, vascular bundle; arrow, tetrads of pollen grains; point arrow, crystalline sand. Scale bars $=50 \mu \mathrm{m}(a), 20 \mu \mathrm{m}(b, e, g, h, j)$ and $10 \mu \mathrm{m}(c, d, f, i, k-o)$. 
parenchymatous in appearance, with thin walls without any fibrous thickening (Fig. 4f). These cells disintegrated by the rupture of their walls, as happened in some cells of the septum, allowing the anther to open and release bicellular pollen grains. Most of the pollen grains were dispersed as monads $(99.6 \%)$ and a small proportion $(0.39 \%)$ as tetrads with a tetrahedral (Fig. $4 h, i, l, m$ ) and decussate arrangement (Fig. $4 j, k, n, o$ ).

\section{Microsporogenesis}

The sporogenous cells characterised by a voluminous size were isodiametrical, with few intercellular spaces and they had a prominent nucleus (Fig. 5a). Mitotic divisions in these cells gave rise to the $\mathrm{mmc}$, which then underwent obvious morphological changes during maturation. The mmc were spherical, uninucleate, with dense cytoplasm and they were surrounded by a callose wall (Fig. $5 b$ ). These cells underwent meiosis, giving rise to four haploid microspores which were arranged in tetrads. The wall of the microspores was formed during simultaneous microsporogenesis and the resulting tetrads were tetrahedral and rarely decussate. The callose wall was retained in both types (Fig. 5c).

\section{Microgametogenesis}

When cytokinesis was complete, the microspores separated from each other and they were free in the locules of the anther due to the dissolution of the callose wall. After becoming free, the unicellular microspores increased in volume considerably due to the formation of a large vacuole and sporopollenin was deposited on the wall (Fig. 5d). The microspores then underwent the first mitotic division that gave rise to a large vegetative cell and a small generative cell arranged laterally. In this bicellular state, the pollen grains were liberated from the sporangium and were characterised by a protruding intine at the pore level, known as an oncus (Fig. $5 e$ ).

Table 1 shows the main events that occurred during anther development of $C$. glabratus, relating ontogeny of the wall of the anther with its different stages of development.

\section{Viability of the pollen grain}

Viability analysis indicated that $95.14 \%$ of the pollen grains were viable and $4.85 \%$ were nonviable. The nonviable grains were identified by the absence of staining in the presence of acetocarmine glycerol and they were smaller than the viable pollen grains, ranging from $9-14 \mu \mathrm{m}$ (Fig. 5f). The viable pollen grains showed intense staining with acetocarmine glycerol jelly and they were between 14 and $23 \mu \mathrm{m}$ in size (Fig. $5 g$ ). The grains dispersed in tetrahedral and decussate tetrads were all viable and their size was similar to that of the monads (Fig. 5h, $i$ ).

\section{Pollen grain morphology and orbicules in American species of Cephalanthus}

The pollen grains of the three species studied were uniform in shape, size, ornamentation, and colpi disposition. The grains were very small to small, circular to subtriangular in polar view (P) (Fig. $6 a-c$ ) and spheroidal in equatorial view (E)
(Fig. 6d-f). Tricolporate ectocolpi were long with a granular membrane and acute ends; mesoporus lolongate with annulus in acetolysed grains (Fig. $6 g-i$ ) or protruding oncus in nonacetolysed pollen grain, the oncus protruded from the mesoporus and was formed by thickening of the intine (Fig. $6 a-c$ ), endoaperture to lolongate pore. The sexine was reticulate in C. glabratus with large, irregular lumens (Fig. 6j), whereas $C$. occidentalis and C. salicifolius had a microreticulate sexine, with lumens more or less regular in size and shape (Fig. 6l, n). The nexine was granular in C. glabratus and C. occidentalis (Fig. 6k, m). The three species had smaller lumens towards the colpi, especially near the mesoporus (Fig. $6 g-i$ ); supratectal elements were absent. All pollinic data of the pollen grains are summarised in Table 2.

The presence of orbicules was detected using optical and scanning electron microscopy. They were associated with the inner wall of mature indehiscent anthers in three American species of Cephalanthus. Orbicules appeared free or in aggregates of two or more elements. They could lie freely upon the locule wall or be embedded in tapetal membrane. They were spheroidal, elongated or pear-shaped and covered the inner surface of the tapetum. In the three studied species, the distribution was uniform, and apparently random, over the tapetal membrane. Data on characteristics of orbicules are summarised in the Table 3.

\section{Discussion}

Ontogeny of the anther wall

Despite scarce studies on the ontogeny of the wall of the anther in the Rubiaceae, the results for Cephalanthus glabratus matched the structure described for other species in this family, for example in Dentella repens and Dentella serpyllifolia (Devi 1980), Tarenna gracilipes (Vinckier and Smets 2005), and some species of tribe Spermacoceae (Galati 1988; Cabaña Fader 2013).

Studies of anther primordia of Arabidopsis (Goldberg et al. 1993; Sanders et al. 1999; Scott et al. 2004) and Schinopsis balansae (Gonzalez 2016) describe the presence of three meristematic regions called L1, L2 and L3, which result in different tissues in the anther. In $C$. glabratus, the epidermis and stomium were differentiated from L1, the L2 layer contributed to the formation of the archespore cells, mmc, endothecium and the middle layer; whereas the L3 layer gave rise to connective tissue and the vascular bundle. The development of the anther wall corresponded to the dicot type proposed by Davis (1966). The middle layer had a common origin with the endothecium, which coincides with the observations in species of tribe Spermacoceae (Galati 1988; Cabaña Fader 2013). Microsporogenesis in C. glabratus was simultaneous, as described for other species of the Rubiaceae (Galati 1988; Vinckier and Smets 2005; Cabaña Fader 2013).

The tapetum was developed by differentiation of the innermost parietal layer. Periasamy and Swamy (1966, in Huysmans et al. 1998) suggest that the tapetum has a dual origin in Angiosperms: in outer regions of the locules the anther originates from the parietal layer and in the innermost regions it is formed from connective tissue. Bhandari (1984) proposed that the tapetum could arise from spore-forming 

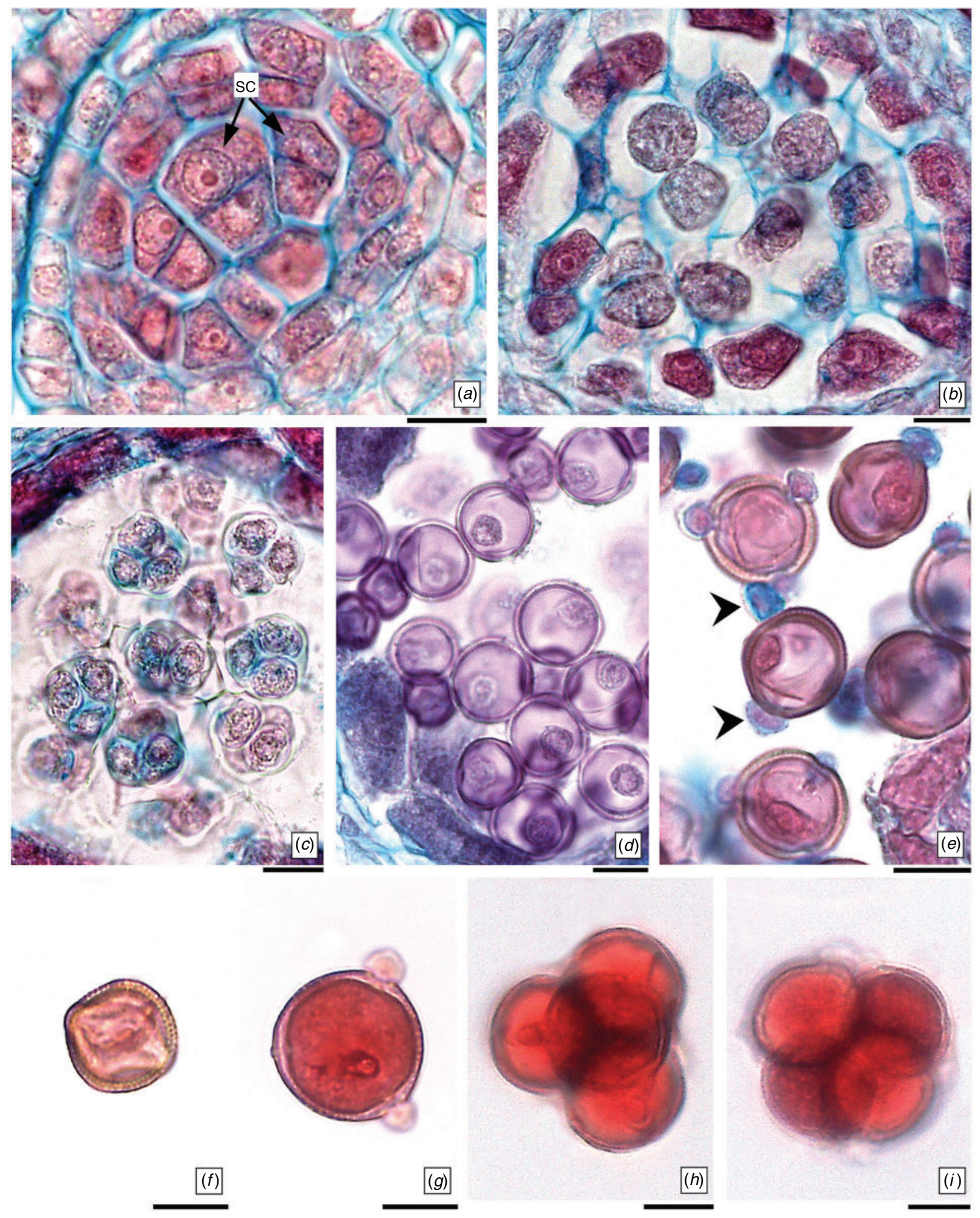

Fig. 5. Microsporogenesis and microgametogenesis in transversal sections with light microscopy, $(a-e)$ and viability of the pollen grain with carmineglycerine in Cephalanthus glabratus $(f-i)$. (a) Anther with sporogenous cells; $(b)$ anther with microspore mother cells $(\mathrm{mmc}) ;(c)$ anther with tetrahedral and decussate tetrads; $(d)$ anther with free microspores; $(e)$ detail of bicellular pollen grains in the oncus (point arrow); $(f)$ sterile pollen grains; $(g)$ viable pollen grains; $(h)$ grains dispersed in viable tetrahedral tetrads; $(i)$ grains dispersed in viable decussate tetrads. Abbreviation: sc, sporogenous cells. Scale bars $=10 \mu \mathrm{m}(a-i)$. 
Table 1. Main events in Cephalanthus glabratus during anther development

Abbreviations: ar, arquesporial cells; cn, connective; e, epidermis; en, endothecium; L1, L2, L3; meristematic layers; ml, middle layer; mmc, microspore mother cells; pc, procambium; sp, septum; str, stomium region; t, tapetum; v, vascular bundle

\begin{tabular}{|c|c|c|c|c|}
\hline $\begin{array}{l}\text { Inflorescence } \\
\text { diameter } \\
(\mathrm{mm})\end{array}$ & $\begin{array}{c}\text { Length } \\
\text { flower }(\mathrm{mm})\end{array}$ & Anther stage & Main morphological events & Tissues present \\
\hline 2.40 & $0.60-0.88$ & 1: Stamen primordium & Periclinal and anticlinal divisions of meristem cells. & L1, L2, L3 \\
\hline 3.68 & $0.79-1.01$ & 2: Arquesporial cells & $\begin{array}{l}\text { Arquesporiales emergence of cells in the four corners of the anther } \\
\text { from the layer L2. }\end{array}$ & $\mathrm{e}, \mathrm{ar}, \mathrm{pc}$ \\
\hline 3.83 & $0.95-1.36$ & 3: Sporogenous cell & $\begin{array}{l}\text { The anther becomes tetralobulated. Mitotic activity in the four } \\
\text { corners of the anther. The region of the septum and stomium } \\
\text { begin to differentiate. The primary parietal layer begins to } \\
\text { divide periclinally to give rise to the middle layer. }\end{array}$ & $\mathrm{e}, \mathrm{en}, \mathrm{ml}, \mathrm{t}, \mathrm{sp}, \mathrm{str}, \mathrm{cn}, \mathrm{v}$ \\
\hline 3.90 & $1.36-1.42$ & $\begin{array}{l}\text { 4: Microspore mother } \\
\text { cells }(\mathrm{mmc})\end{array}$ & $\begin{array}{l}\text { The four lobes are well defined. mmc appear surrounded by } \\
\text { callose. Anther increases the size, tapetum is vacuolated and the } \\
\text { middle layer begins to degenerate. }\end{array}$ & $\mathrm{e}, \mathrm{en}, \mathrm{ml}, \mathrm{t}, \mathrm{sp}, \mathrm{str}, \mathrm{cn}, \mathrm{v}$ \\
\hline 6.29 & $2.07-2.30$ & 5: Tetrads & $\begin{array}{l}\text { Tetrads of microspores are shown within each lobe. Callose wall } \\
\text { remains around the tetrads. }\end{array}$ & e, en, t, sp, str, cn, v \\
\hline 6.54 & $2.24-2.39$ & 6: Free microspores & $\begin{array}{l}\text { Unicellular microspores are released in locule. Tapetal cells } \\
\text { preserve their size and dense cytoplasm. The middle layer has } \\
\text { collapsed. }\end{array}$ & $\mathrm{e}, \mathrm{en}, \mathrm{t}, \mathrm{sp}, \mathrm{str}, \mathrm{cn}, \mathrm{v}$ \\
\hline 8.56 & $2.02-3.28$ & 7: Pollen grain & $\begin{array}{l}\text { The anthers contain pollen grains of two-cells and begin to prepare } \\
\text { for dehiscence. The thickenings of endothecial form, the } \\
\text { tapetum begins to degenerate and orbicules are evident. Septal } \\
\text { tissue collapses. Oncus is observed in the mature pollen grains. }\end{array}$ & e, en, t, str, cn, v \\
\hline 10.47 & $4.96-5.49$ & 8: Anther dehiscence & $\begin{array}{l}\text { Anther dehiscence occurs with the rupture of stomium and pollen } \\
\text { grains are free. The anthers wall preserved remains of epidermis } \\
\text { and endothecium. Dispersed pollen grains retain the oncus. }\end{array}$ & $\mathrm{e}, \mathrm{en}, \mathrm{cn}, \mathrm{v}$ \\
\hline
\end{tabular}

tissue. Accordingly, the tapetum could arise from the development and differentiation of the meristematic layers, L2 and L3, which give rise to spore-forming tissue and connective tissue respectively.

The presence of idioblasts with crystal sand in the septum was consistent with previous observations (Vinckier and Smets 2005) of druses of calcium oxaloacetate in the region of the septum and connective tissue of the anther at the mmc stage in Tarenna gracilipes (Rubiaceae). Vinckier and Smets (2005) proposed that the crystals are released during anther dehiscence and provide a possible visual signal to pollinators. Mauseth (1988) notes that there may be cells with calcium oxalate in the region of anther dehiscence, which would function as a defence against insects that feed on pollen. Horner and Wagner (1992), who studied anthers of Capsicum annuum, considered that the cells normally producing calcium crystals are generally young cells in the differentiation process. Crystal formation in the connective tissue of the anthers of some Solanaceous species begins at an early stage of development. This would indicate that calcium crystals are part of a complex development process culminating in the orderly self-destruction of this tissue and are associated with anther dehiscence.

In C. glabratus, the presence of crystals in the septal cells might operate in the process of locule fusion and breaking of the stomium, with the consequent release of pollen grains from the anther.

Cephalanthus glabratus has a secretory tapetum, as previously described for other species of Rubiaceae (Devi 1980; Galati 1988; Vinckier and Smets 2005; Cabaña Fader 2013).

\section{Orbicules}

Orbicules were observed in the mature anthers of all three species of Cephalanthus. Their size varied from $0.56-0.87 \mu \mathrm{m}$ (in free orbicules) to $1.0-1.8 \mu \mathrm{m}$ in diameter (in aggregate ones) in $C$. occidentalis and C. salicifolius. In C. glabratus, only aggregate orbicules were found, varying from 0.50 to $1.76 \mu \mathrm{m}$ in diameter.

According to the classification by Verstraete et al. (2011), the orbicules of Cephalanthus species are of medium size $(0.50-0.87 \mu \mathrm{m})$ when the orbicules are free, and large size $(>1 \mu \mathrm{m})$ when they are aggregates. According to Galati (2003), in angiosperms the most common forms are spherical to subspherical, or pear-shaped when observed externally, which represented the only shapes recorded for Cephalanthus species. Based on a typology proposed by Huysmans et al. (1998), and followed by Vinckier et al. (2000) and Vinckier and Smets (2002), the orbicules found in Naucleeae are classified as type $3 \mathrm{a}$ (spheroidal, with smooth surfaces and a central notch), which corresponds with the most common type in the subfamily Cinchonoideae. In addition, Verstraete et al. (2011) mentioned the presence of medium-size orbicules (ranging from $0.50-1.0 \mu \mathrm{m}$ in diameter) and larger orbicules $(>1 \mu \mathrm{m}$ in diameter) for Cinchonoideae. These authors hypothesised that small orbicules $(<0.5 \mu \mathrm{m})$, spheroidal and with smooth or pitted surfaces represent a plesiomorphic character in Rubiaceae. They also proposed an evolutionary trend, in which the most derived lineages of the family would have larger and fewer orbicules, with irregular and ornamented surfaces. Following these trends, we could affirm that the 

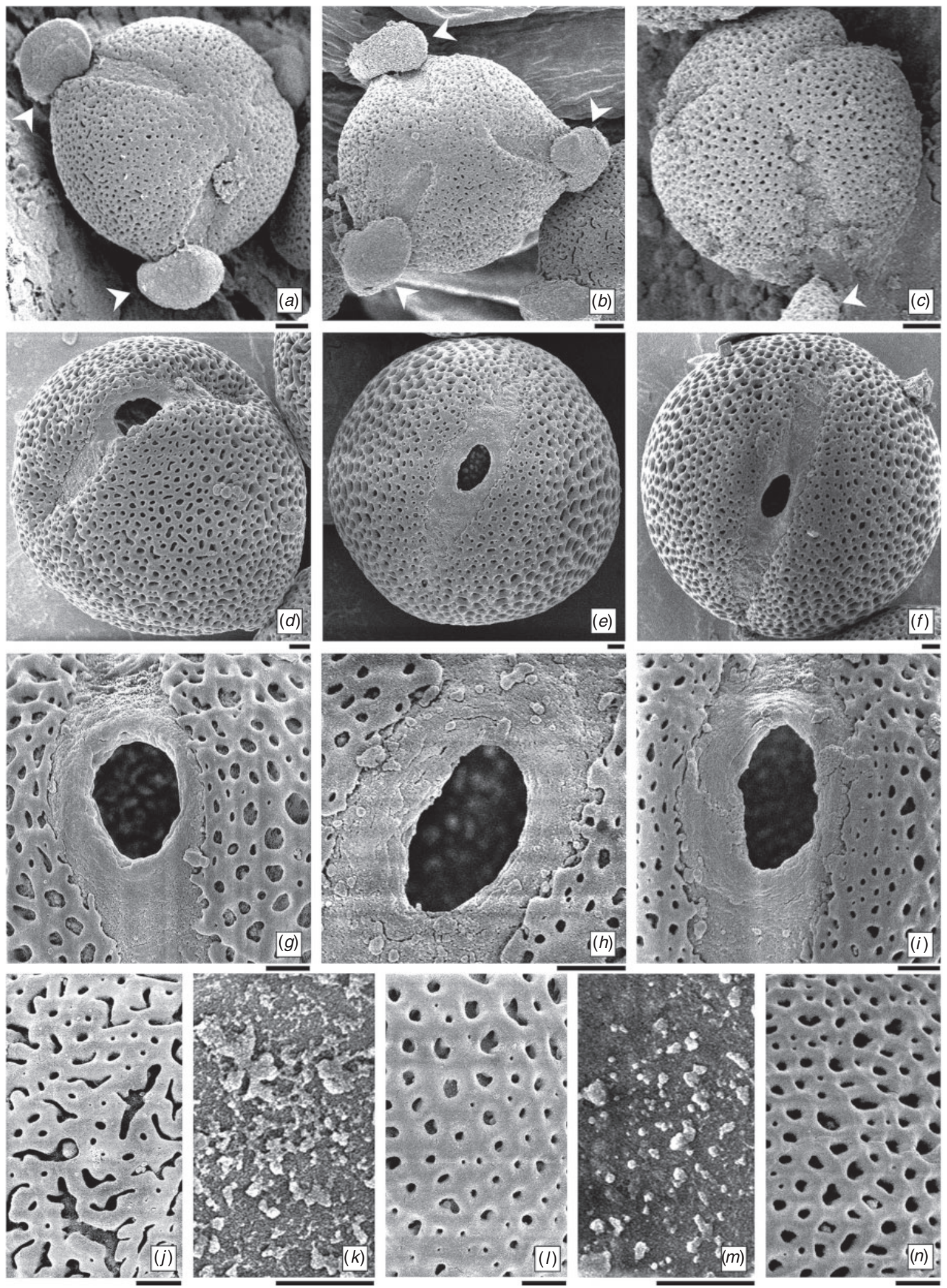

Fig. 6. Pollen grains in surface view with scanning electron microscopy in American species of Cephalanthus. $(a, d$, g, $j, k)$ Cephalanthus glabratus; $(b, e, h, l, m)$ Cephalanthus occidentalis; $(c, f, i, n)$ Cephalanthus salicifolius. (a-c) Pollen grains without acetolysis with oncus (point arrow); $(d-f)$ acetolysed pollen grains; $(g-i)$ detail of the pore; $(j, l, n)$ detail of the sexine; $(k, m)$ detail of the nexine. Scale bars $=2 \mu \mathrm{m}(a-c)$ and $1 \mu \mathrm{m}(d-n)$. 

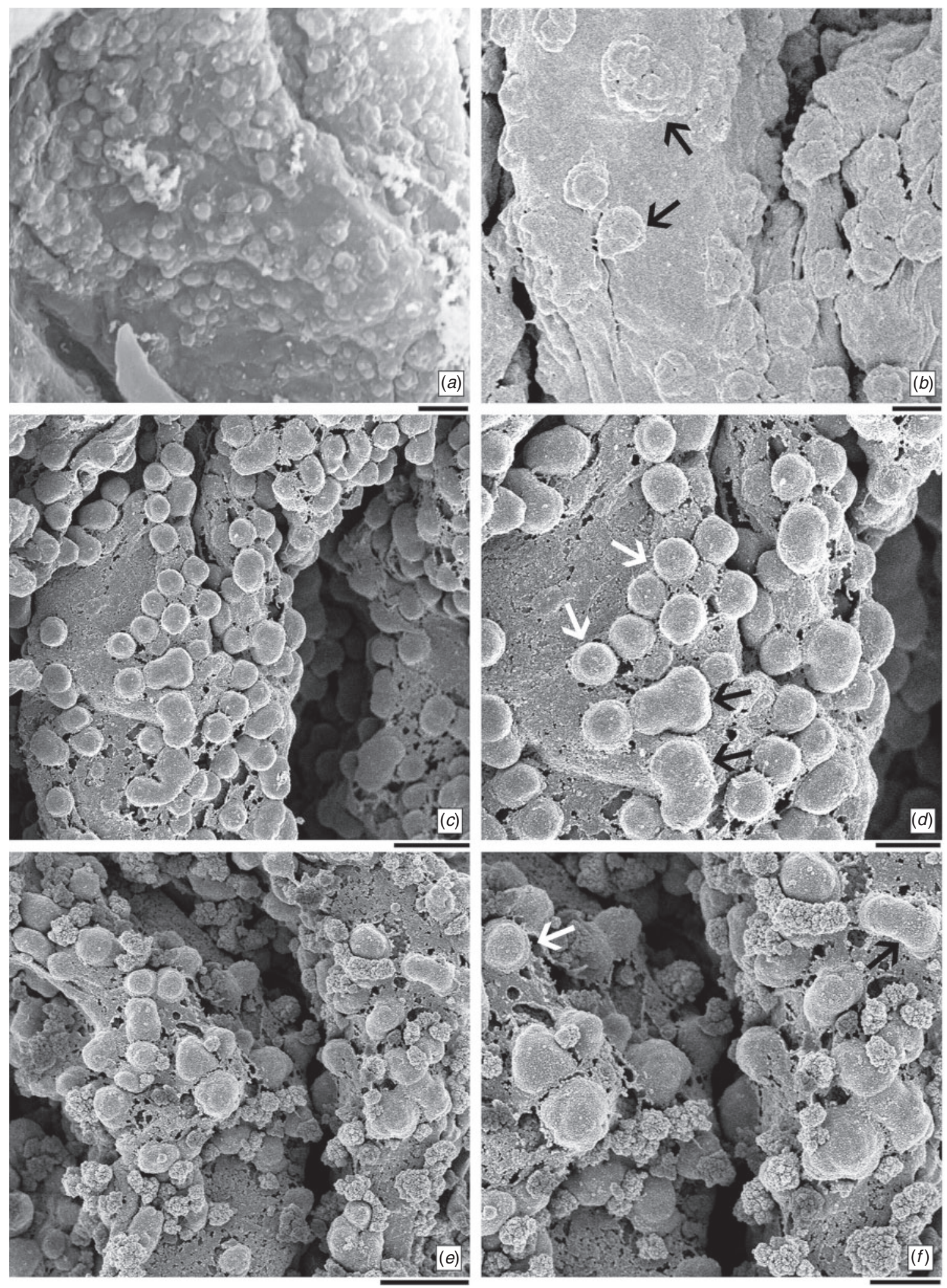

Fig. 7. Orbicules in surface view with scanning electron microscopy in American species of Cephalanthus. (a, b) Cephalanthus glabratus. (a) Orbicules embedded in the tapetal membrane; $(b)$ aggregates of spheroidal to subspheroidal orbicules with a smooth to rough surface; $(c, d)$ Cephalanthus occidentalis; $(c)$ free orbicules in the tapetal membrane; $(d)$ free spheroidal orbicules and aggregates of pyriform orbicules with smooth surfaces; $(e, f)$ Cephalanthus salicifolius; $(e)$ free orbicules in the tapetal membrane; $(f)$ aggregate of spheroidal and elongate orbicules with smooth surfaces. Abbreviations: black arrow, aggregates orbicules; white arrow, free orbicules. Scales bars $=2 \mu \mathrm{m}(a, c, e)$ and $1 \mu \mathrm{m}(b, d, f)$. 
Table 2. Measurements of pollen in American Cephalanthus

\begin{tabular}{|c|c|c|c|c|c|c|c|c|}
\hline \multirow[t]{2}{*}{ Species } & \multicolumn{2}{|c|}{ Size } & \multicolumn{2}{|c|}{ Exine thickness } & \multirow[t]{2}{*}{ Sexine pattern } & \multirow[t]{2}{*}{ Nexine pattern } & \multirow[t]{2}{*}{ Lumen $(\mu \mathrm{m})$} & \multirow[t]{2}{*}{ Tectum } \\
\hline & $\mathrm{P}(\mu \mathrm{m})$ & $\mathrm{E}(\mu \mathrm{m})$ & Sexine $(\mu \mathrm{m})$ & Nexine $(\mu \mathrm{m})$ & & & & \\
\hline C. glabratus & $15.08-20.68$ & $14.74-22.93$ & $0.60-1.03$ & $0.35-1.58$ & Reticulate & Granular & Heterobrochate $0.06-1.70$ & Semitectate \\
\hline C. occidentalis & $14.31-21.63$ & $15.65-21.16$ & $0.53-1.15$ & $0.90-1.62$ & Microreticulate & Granular & Homobrochate $0.09-0.59$ & Tectate \\
\hline C. salicifolius & $17.62-21.57$ & $18.33-20.65$ & $0.65-1.10$ & $0.72-1.44$ & Microreticulate & Not observed & Homobrochate $0.11-0.54$ & Tectate \\
\hline
\end{tabular}

Table 3. Characteristic of orbicules in three American species of Cephalanthus Abundance abbreviations: a, abundant; va, very abundant; s, scattered. Shape abbreviations: sph, spherical; sbsph, subspherical; pe, pear; el, elongated. Ornamentation abbreviations: rough, wavy edges-irregular; sm, smooth. Association abbreviations: agg, aggregated; em, embedded; fr, free

\begin{tabular}{lccccc}
\hline Species & Abundance & Size $(\mu \mathrm{m})$ & Shape & Ornamentation & Association \\
\hline C. glabratus (Fig. 7a, $b$ ) & $\mathrm{a}$ & $0.50-1.76$ & sph-sbsph & rough & agg; em \\
C. occidentalis (Fig. 7c, $d$ ) & $\mathrm{va}$ & $0.62-0.78$ & $\mathrm{sph}$ & $\mathrm{sm}$ & $\mathrm{fr}$ \\
& $\mathrm{s}$ & $1.0-1.8$ & pe-el & $\mathrm{sm}$ & $\mathrm{agg}$ \\
C. salicifolius (Fig. 7e, $f$ ) & $\mathrm{va}$ & $0.56-0.87$ & $\mathrm{sph}$ & $\mathrm{sm}$ & $\mathrm{fr}$ \\
& $\mathrm{s}$ & $1.0-1.4$ & $\mathrm{sph}-\mathrm{el}$ & $\mathrm{sm}$ & agg \\
\hline
\end{tabular}

orbicules of $C$. glabratus represented a more derived state than those of $C$. occidentalis and $C$. salicifolius. According to the genera analysed by Verstraete et al. (2011) for the tribe Naucleeae, C. glabratus shares similar characteristics to Breonadia salicina, with both having irregular orbicules and a rough surface. However, C. occidentalis and C. salicifolius have similarities with Uncaria africana, having several orbicules, with spherical shape and smooth surface. The results of this work expand the information on the tribe Naucleeae, especially for Cephalanthus.

The orbicules of the American species of Cephalanthus have taxonomic value at species level, since these structures allow us to distinguish between the species analysed. Further investigations with transmission electron microscopy to confirm the presence of a core in the orbicules and to study its ontogeny are needed in these and other species of the genus.

\section{Pollen grains}

The presence of a protruding oncus was observed for the first time in Cephalanthus in non-acetolysed pollen grains. These structures are reported in other species of Rubiaceae (Galati 1988; Vinckier and Smets 2005; Kuang et al. 2008, 2012). Onci may be affected by the use of acetolysis, which can lead to the failure to report intinous structures and may even distort some aspects of pollen, causing faulty reports of pollen diameter, sculpturing and shape (Hesse and Waha 1989). However, in this study, the acetolysis technique did not affect morphology of the pollen grains. Kuang et al. (2012) consider that the presence of onci is also affected by the stage of anther dehiscence. Before anther dehiscence, onci are almost universally present and conspicuously visible in the grains. At anther dehiscence, onci are usually absent and, when present, they are small and undistinguished. These changes are likely due to the harmomegathic effect, which occurs after anther dehiscence. According to our observations, this structure is not affected by the state of anther dehiscence in C. glabratus, because the oncus is visible and prominent in mature pollen grains in both indehiscent and dehiscent anthers. In C. glabratus, the oncus is visible at the pollen grain stage, moments before dehiscence. This is consistent with descriptions by Vinckier and Smets (2005) for Tarenna gracilipes. However, the time of onci formation is dependent on the taxon, as the formation of this structure at the tetrad or microspore stage has been reported for the Rubiaceae (Kuang et al. 2012).

Verellen et al. (2007) described the tribe Naucleeae as a taxon with small $(20-30 \mu \mathrm{m})$ to very small pollen grains $(>20 \mu \mathrm{m})$. These authors also indicate that Cephalanthus is one of the genera with largest pollen grains $(20-25 \mu \mathrm{m})$ and, according to our observations, the grains do not exceed $23 \mu \mathrm{m}$. In contrast to work by Verellen et al. (2007), who mentioned that the pollen grains in the tribe Naucleeae are always released in monads, we found permanent tetrads in C. glabratus as well as monads but in a lower proportion $(0.39 \%)$. This finding represents the first record for this species and the tribe Naucleeae.

\section{Acknowledgements}

The authors thank the curators of Herbarium CTES, collectors of material used for the palynogical studies. We also thank W Medina, S Martin, A Avalos and J Florentin for providing fixed materials, and Rosemary Scoffield for her contributions that improved the English manuscript. This work received a grant from the Universidad Nacional del Nordeste (PICTO 199/2011).

\section{References}

Arbo MM, López A, Schinini A, Pieszko G (2002) Las Plantas Hidrófilas. In 'Flora del Iberá'. (Eds MM Arbo, SG Tressens) pp. 9-110. (EUDENNE: Corrientes, Argentina)

Bacigalupo NM (1974) Rubiaceae. 6a. In 'Flora Ilustrada de Ríos'. (Ed. AE Burkart) pp. 3-50. (Instituto Nacional de Tecnología Agropecuaria: Buenos Aires) 
Bhandari NN (1984) The microsporangium. In 'Embryology of Angiosperms'. (Ed. BM Johri) pp. 53-121. (Springer-Verlag: Berlin)

Bremer B, Eriksson T (2009) Time tree of Rubiaceae: phylogeny and dating the family, subfamilies, and tribes. International Journal of Plant Sciences 170, 766-793. doi:10.1086/599077

Bremer B, Jansen RK, Oxelman B, Backlund M, Lantz H, Kim KJ (1999) More characters or more taxa for a robust phylogeny case study from the coffee family (Rubiaceae). Systematic Biology 48, 413-435. doi:10.1080/106351599260085

Cabaña Fader AA (2013) Estudios Biosistemáticos en especies americanas de Diodia s.lat. (Rubiaceae). Doctoral Thesis, Facultad de Ciencias Exactas y Naturales y Agrimensura, Universidad Nacional del Nordeste, Argentina.

Cabrera AL, Zardini EM (1978) 'Manual de la flora de los alrededores de Buenos Aires.' (ACME: Buenos Aires)

Davis GL (1966) 'Systematic embryology of the Angiosperms.' (Wiley: New York)

Dessein S, Ochoterena H, De Block P, Lens F, Robbrecht E, Schols P, Smets E, Vinckier S, Huysmans S (2005) Palynological characters and their phylogenetic signal in Rubiaceae. Botanical Review 71, 354-414. doi:10.1663/0006-8101(2005)071[0354:PCATPS]2.0.CO;2

Devi H (1980) Embryology of two species of Dentella (Dentella repens and Dentella serpyllifolia). Proceedings of the Indian Academy of Sciences: Plant Sciences 89, 213-218.

Erdtman G (1960) The acetolysis method. Svensk Botanisk Tidskrift 54, 561-564.

Galati BG (1988) Estudios embriológicos en la tribu Spermacoceae (Rubiaceae). $\mathrm{PhD}$ thesis, Universidad de Buenos Aires, Argentina.

Galati BG (1991) Estudios embriológicos en la tribu Spermacoceae (Rubiaceae). Parte I: Anatomía floral. Microsporogénesis. Megasporogénesis. Boletín de la Sociedad Argentina de Botánica 27(1-2), 7-20.

Galati BG (2003) Ubisch bodies in Angiosperms. In Advances in plant reproductive biology. Vol. II'. (Eds AK Pandey, MR Dhakal) pp. 1-21. (Narendra Publishing House: Delhi)

Galati BG, Goteli MM, Rosenfeldt S, Torretta JP, Zarlavsky G (2010) Orbicules in relation to the pollination modes. In Pollen: structure, types and effects'. (Eds BJ Kaiser) pp. 1-15. (Nova Science Publishers Inc.: New York)

Goldberg RB, Beals TP, Sanders PM (1993) Anther development : basic principles and practical applications. The Plant Cell 5, 1217-1229. doi:10.1105/tpc.5.10.1217

Gonzalez AM (2016) Floral structure, development of the gynoecium, and embryology in Schinopsis balansae Engler (Anacardiaceae) with particular reference to aporogamy. International Journal of Plant Sciences 177, 326-338. doi:10.1086/684847

Gonzalez AM, Cristóbal CL (1997) Anatomía y ontogenia de semillas de Helicteres lhostzkyana (Sterculiaceae). Bonplandia 9, 287-294.

Hesse M, Waha M (1989) A new look at the acetolysis method. Plant Systematics and Evolution 163, 147-152. doi:10.1007/BF00936510

Horner HT, Wagner BL (1992) Association of four different calcium crystals in the anther connective tissue and hypodermal stomium of Capsicum annuum (Solanaceae) during microsporogenesis. American Journal of Botany 79(5), 531-541. doi:10.2307/2444864

Huysmans S, El-Ghazaly G, Smets E (1998) Orbicules in Angiosperms: morphology, function, distribution, and relation with tapetum types. Botanical Review 64, 240-272. doi:10.1007/BF02856566

Huysmans S, El-Ghazaly G, Nilsson S, Smets E (1997) Systematic value of tapetal orbicules: a preliminary survey of the Cinchonoideae (Rubiaceae). Canadian Journal of Botany 75, 815-826. doi:10.1139/b97-091

Hyde HA (1955) Oncus, a new term in pollen morphology. New Phytologist 54, 255-256. doi:10.1111/j.1469-8137.1955.tb06177.x
Inamuddin M, Farooq M (1984) The embryology of Richardia brasiliensis Gomes (syn. Richardsonia pilosa H.B. \& K.) (Rubiaceae) - a reinvestigation. Pakistan Journal of Botany 16, 139-144.

Johansen DA (1940) 'Plant microtechnique.' (Mc Graw-Hill Book Co. Inc.: New York)

Kandus P, Morandeira N, Schivo F (2010) 'Bienes y Servicios Ecosistémicos de los Humedales del Delta del Paraná.' (Wetlands International: Fundación Humedales)

Kuang YF, Kirchoff BK, Tang YJ, Liang YH, Liao JP (2008) Palynological characters and their systematic significance in Naucleeae (Cinchonoideae, Rubiaceae). Review of Palaeobotany and Palynology 151, 123-135. doi:10.1016/j.revpalbo.2008.03.003

Kuang YF, Kirchoff BK, Liao JP (2012) Presence of the protruding oncus is affected by anther dehiscence and acetolysis technique. Grana $\mathbf{5 1}$, 253-262. doi: $10.1080 / 00173134.2012 .660984$

Luque RH, Souza C, Kraus JE (1996) Métodos de coloracão do Roeser (1972) Modoficado - E Kropp (1972), visado a substituicão do azul de astra por azul de alcião 8GS on 8GX. Acta Botanica Brasílica 10, 199-212.

Manns U, Bremer B (2010) Molecular phylogenetics and evolution towards a better understanding of intertribal relationships and stable tribal delimitations within Cinchonoideae s. s. (Rubiaceae). Molecular Phylogenetics and Evolution 56, 21-39. doi:10.1016/j.ympev.2010.04.002

Marks GE (1954) An aceto-carmine glycerol jelly for use in pollen fertility counts. Stain Technology 29, 277-277. doi:10.3109/10520295409115483

Martínez Crovetto RN (1981) Las plantas utilizadas en medicina popular en el Noroeste de Corrientes-Argentina. Miscelánea 69, 1-140.

Mauseth JD (1988) 'Plant anatomy.' (The Benjamin/Cummings Publishing Company: Menlo Park, CA, USA)

Muntzing A (1941) Differential response to x-ray treatment of diploid and tetraploid barley. Kungl Fysiograf Sallskapets Lund Förhand 11, 1-10.

Nilsson S, Praglowski J (1992) 'Erdtman's handbook of palynology.' (2nd edn) (Munksgaard: Copenhagen)

O'Brien TP, Feder N, McCully ME (1964) Polychromatic staining of plant cell walls by toluidine blue. Protoplasma 59(2), 368-373. doi:10.1007/BF01248568

Periasamy K, Swamy BGL (1966) Morphology of the anther tapetum in angiosperms. Current Science 35, 427-430.

Punt W, Hoen PP, Blackmore S, Nilsson S, Le Thomas A (2007) Glossary of pollen and spore terminology. Review of Palaeobotany and Palynology 143, 1-81. doi:10.1016/j.revpalbo.2006.06.008

Ridsdale CE (1976) A revision of the tribe Cephalantheae (Rubiaceae). Blumea 23(1), 177-188.

Robbrecht E (1988) Tropical woody Rubiaceae. Opera Botany Belgica 1, $1-176$.

Sanders PM, Bui AQ, Weterings K, McIntire KN, Hsu YC, Lee PY, Truong MT, Beals TP, Goldberg RB (1999) Anther developmental defects in Arabidopsis thaliana male-sterile mutants. Sexual Plant Reproduction 11, 297-322. doi:10.1007/s004970050158

Schleiden MJ (1837) Einige Blickeauf die Entwicklungsgeschichte des vegetabilischen Organismusbei den Phanerogamen. Archiv für Naturgeschichte 1, 289-320.

Scott RJ, Spielman M, Dickinson HG (2004) Stamen structure and function. The Plant Cell 16, S46-S60. doi:10.1105/tpc.017012

Siegloch AM, Marchiori JNC, dos Santos SR (2011) Anatomia do lenho de Cephalanthus glabratus (Spreng.) K. Schum. (Rubiaceae). Balduinia 31, 20-26.

Verellen J, Dessein S, Razafimandimbison SG, Smets E, Huysmans S (2007) Pollen morphology of the tribes Naucleeae and Hymenodictyeae (Rubiaceae-Cinchonoideae) and its phylogenetic significance. Botanical Journal of the Linnean Society 153, 329-341. doi:10.1111/j.1095-8339.2006.00604.x 
Verstraete B, Groeninckx I, Smets E, Huysmans S (2011) Phylogenetic signal of orbicules at family level: Rubiaceae as case study. Taxon 60, 742-757.

Vinckier S, Smets E (2002) Systematic importance of orbicule diversity in Gentianales. Grana 41, 158-182. doi:10.1080/001731302321042623

Vinckier S, Smets E (2005) A histological study of microsporogenesis in Tarenna gracilipes (Rubiaceae). Grana 44, 30-44.

doi:10.1080/00173130510010530
Vinckier S, Huysmans S, Smets E (2000) Morphology and ultrastructure of orbicules in the subfamily Ixoroideae (Rubiaceae). Review of Palaeobotany and Palynology 108, 151-174.

doi:10.1016/S0034-6667(99)00036-6

Handling Editor: Stephen Trueman 